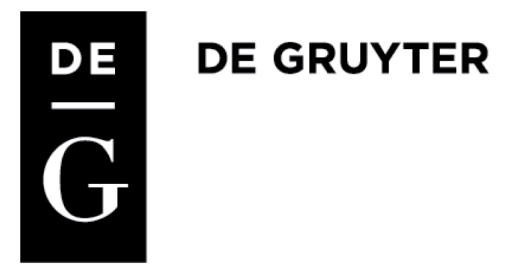

Robert Jastrzębski (University of Warsaw)

\title{
CURRENCY REFORMS IN THE POLISH STATE AFTER 1945. LEGALECONOMIC ISSUES
}

The subject of the article are currency reforms that were carried out after the Second World War in the Polish state. The first legal regulations from 1944 - 45 concerned the unification of the money circulation, which in practice meant the exchange of occupation money for the new currency. However, the repayment of financial claims made before the outbreak of the war was regulated by a decree of 1949. Another monetary reform concerned the new, socialist economic policy of the Polish state. The basis for it was the Act of October 28, 1950 on the change of the monetary system. After this reform, periodic changes in prices and wages were introduced, which were not based on strictly legislative solutions. In practice, these ordinances were in the nature of new monetary reforms. The Act of 1950 was repealed by the Act of 7 July 1994 on the denomination of the zloty.

Keywords: currency reforms, inflation, deflation, monetary nominalism, valorization

doi:10.1515/sho-2017-0007

\section{PRELIMINARY ISSUES}

The concept of currency reform is related to the economic recovery of the state and most often concerns the introduction of a new cash measure into circulation, i.e. a new currency. It is to replace the current payment instrument, which is most often the so-called inflation money. Currency reforms are usually the result of a state-led inflation policy aimed at satisfying current economic needs. Such a policy is connected with the imposition of the so-called inflationary tax by the state [Szturm de Sztrem T. 1923; Rybarski R. 1935: 197-198; Dalton H. 1948: 164-168]. In connection with this, as Jan Wasilkowski stated:

In periods of crisis caused by economic or political events (primarily war) the state is forced to look for sources of income in the issuance of currency, nominalism is a conditio sine qua non of this method of financing public expenditure. Losses incurred by individual units then, due to a drop in the value of income and property, determined 
numerically in cash, can be painful; however, they are unavoidable if the issue is to fulfil its purpose, that is, to provide purchasing power to meet social needs that cannot be met otherwise [Wasilkowski J. 1948: 44].

In this way, the state uses one of the characteristics of money, i.e. exemption from obligations, both public and private law. This means that the state can conduct a specific economic policy related to the change in the purchasing power of money, in particular its reduction, which results directly from the increase in money emission. This kind of policy was carried out already in antiquity, and in the Middle Ages it was referred to as the 'spoilage of coins', while recognizing that monetae sunt regales [Stelmachowski A. 1965: 282 et seq.]. Inflation phenomena that currency reforms involve often have an impact on economic development. Such opinion was expressed, amongst others, Henryk Gruber, who explicitly stated that "progress goes hand in hand with the development of inflation processes, without which the world would be stuck in the conditions of the Middle Ages" [Gruber H. 1968: 310]. It is worth noting that in the 20th century, the essence of money, including its functions, was variously defined. This was mainly due to two world wars, the great economic crisis of the 1930s and the doctrine of socialist economics [See more: Fedorowicz Z. 1962; Fedorowicz Z. 1975; Żabiński Z. 1988; Kosikowski C. 1990].

Money is both the subject of economic and legal phenomena. In the latter case, it should be recognized that it is a monetary unit defined by the state, by means of legal regulations, which has the ability to release from obligations by payment [Orłowski M. 1937: 1448; Żabiński Z. 1972]. An important role from the legal point of understanding the essence of money has two basic theories. The former one, called nominalism, assumes that money is a product of the legal order, and therefore has the character of an abstract accounting unit. The latter one - metallistic, assumes that money has a certain economic value (commodity) [Żabiński Z. 1965]. Before the outbreak of the First World War, the issue of money was based mainly on gold (the so-called gold standard). After the end of the war, the system of issuing cash marks was referred to as the gold-exchange currency (the so-called gold exchange standard). It is worth noting that the creation of the last system was associated with the figure of an outstanding Polish lawyer and economist Leon Biliński, who before the outbreak of the First World War, fulfilling important functions in the Austro-Hungarian monarchy, had introduced the last of the currency systems in the dualistic monarchy 
[Biliński L. 1924: 147 et seq.]. Subsequent changes in determining the essence of money were related to the great economic crisis of the 1930s and to J. M. Keynes, who essentially assumed that money can be one of the instruments to get out of the crisis and the state can shape its circulation in a way that meets specific needs. [Kalecki M. 1936; Keynes J. M. 1985]. At the end of the Second World War, the attempt to return to the currencyzloty (PLN) exchange system was an agreement at the Bretton Woods conference in July 1944 [Langrod R. 1946; Karpiński Z. 1964: 9 et seq.; Piłejko K. 1971: 185 et seq.].

Conducting currency reforms during the Second Polish Republic was connected with the creation of a new state on the European continent. In the first place, they resulted from the inflation policy conducted by the state, which in practice consisted in printing the Polish brand by the Polish National Loan Fund. [Rybarski R. 1922: 3 et seq.; Karpiński Z. 1968: 29 et seq.; Taylor E. 1926; Morawski W. 2008]. In this way, the Polish state found a source of income that enabled it to function at all, because the financial resources inherited from the period of partitions were in fact a substitute for money. The inflation policy carried out since 1918 had to be finally terminated due to the progressive hyperinflation. This was due to the fact that hyperinflation did not bring any benefits to the state, and even became dangerous, because, as Feliks Młynarski stated, "economic life, like nature, however, does not know its rights and miracles" [Młynarski F. 1925: 62]. Therefore, it was necessary to carry out currency and economic reforms, and thus break with the current inflation policy. After stabilizing the zloty, the so-called post-inflation crisis, referred to as the second Polish inflation took place [Taylor E. 1926; Grabski Wł. 1927: 176 et seq.; Grabski Wł. Druga inflacja...1927]. Finally, in 1927, the rules of the new monetary system were defined, which basically did not change until the outbreak of the Second World War [Landau Z. 1963; Karpiński Z. 1968: 101 et seq.; Zajda J. 1986: 36 et seq.].

It should be emphasized that in Poland, the phenomenon of inflation before the outbreak of the Second World War had a different character than after 1945 that is in the period of People's Poland, and from 1952, the Polish People's Republic ${ }^{1}$. It resulted from a different economic structure influenced by political and social ideology of socialism. That is why inflation in both periods differed in genesis, course and effects [See more:

1 The name of the Polish state resulted from the entry into force of the Constitution of the Polish People's Republic of 22 July 1952 (Journal of Laws No. 33, item 232). 
Rutkowski J. 1989: 13 et seq.; Landau Z., Roszkowski W. 1995: 127 et seq.]. This was due to the fact that the socialist economy was a centrally planned economy. Therefore, inflation took the form of the so-called dampened inflation, and money was one of the elements of the implementation of economic plans [See more: Winiecki J. 1986: 171 et seq.; Belka M. 1994: 283285; Landau Z. Roszkowski W. 1995: 133-134; Kurowski S. 1990: 153 et seq.; Jastrzębski R. 2013].

\section{CURRENCY REFORMS AFTER 1945}

As a result of the outbreak of the Second World War, the area of the Polish state was under the control of the occupiers who had exchanged the zloty for their own currencies - the German Mark and the ruble. The exception was the General Governorship, for which the issuing institution was the Bank of Issue in Poland, whose statute was announced in mid-December 1939. The Bank commenced its activities at the beginning of April 1940. Its first activity was exchanging tickets of the Bank of Poland to the tickets of the Bank of Issue in Poland. The activity of this issuing institution in practice resembled the functioning of the Polish National Loan Fund during the First World War, it was inflationary, and the cash circulation (the so-called Zloty Krakowski) increased by more than five times at the end of the German occupation, namely around 2 billion - the Bank's ticket exchange period Polskie, to over 10 billion - the end of the German occupation [Karpiński Z. 1968: 157-166]. It was one of the forms of exploitation of the occupied Polish territories, which was used in other countries, e.g. in the Netherlands, Belgium, Denmark, France, Norway, Greece, Yugoslavia, Czechoslovakia [Karpiński Z. 1968: 174-175; Skubiszewski K. 1960; Skubiszewski K. Pieniadz na ...1960: 93 et seq.]. This kind of politics aptly described, before the outbreak of the Second World War, Witold Krzyżanowski, as "a kind of modern war contribution, collected in a mild form of a drug, in the form of inflation tax" [Krzyżanowski W. 1938: 134].

After the end of the war, the currency situation resembled 1918, with a different political situation taking place. In connection with this, as Zbigniew Landau stated:

the liquidation of the monetary mosaic was one of the necessary conditions for regulating trade, unifying the system of prices and wages, providing the central govern- 
ment with the possibility to influence the course of financial processes [Landau Z. 1968: 59].

In practice, the new People's Authority had to: set up a new issuing institution, unify the monetary circulation in the territory of the Polish state, and thus put into circulation a new monetary unit (monetary marks) whose inventory should have been previously stored. It is worth noting that the then area of the Polish state still included the area of war operations, and the state borders were not finally established. The first printing of banknotes was made in the Union of Soviet Socialist Republics (hereinafter: the USSR), however, due to their improper print and a small amount, they were not put into circulation. Then, in January 1945, new banknotes were printed in Moscow for a nominal amount of about PLN 8.5 billion [Karpiński Z. 1968: 168-169]. The issue was taken up by the Central Treasury Office, established on the basis of a decree of the Polish National Liberation Committee (hereinafter: PNLC) of August 24, 1944 on the issue of treasury tickets [ Dz. U. (Journal of Laws) Nr 3, pos. 11.]. According to the decree, the issued tickets were to have the inscription: 'National Bank of Poland'. In addition, the decree allowed for trade: the Soviet ruble in the ratio of 1 ruble $=1$ PLN, 1 Chervonet $=10$ PLN, and the Bank of Issue tickets were to continue to run at a rate of one to one against the new currency. Then in January 1945 a decree was issued on the National Bank of Poland, pursuant to art. 1 of the decree:

In order to regulate the circulation of money and credit, a state institution called the National Bank of Poland is called into being, equipped by the State with the privilege of issuing bank tickets $(. . .)^{2}$.

The uniformity of the monetary circulation in the territory of the Polish state took place gradually, based on legal acts issued by the then people's authorities. These acts concerned These acts concerned specific areas included in the forming Polish state. Among them should be included:

1) Decree of the PCLN of October 23, 1944 on the withdrawal from circulation of the German brand in the area of the Bialystok Province [ Dz. U. (Journal of Laws) Nr 9, pos. 43.], according to which the Mark lost the nature of the currency on October 28, 1944, and the exchange of the Mark was to be made at DEM 1 = PLN 1 up to 300 marks per person;

2 Decree of January 15, 1945 on the National Bank of Poland, Dz. U. (Journal of Laws) No. 4, item 14. 
2) decree of January 6, 1945 on the deposit and exchange of banknotes of the Bank of Issue in Poland [ Dz. U. (Journal of Laws) Nr 1, pos. 2.], according to which the tickets of the Bank of Issue in Poland, so-called Krakow banknotes ceased to be a circulatory currency in the Polish state as of 10 January 1945, with the exchange for tickets of the National Bank of Poland was to ensue by 28 February at a one-to-one exchange rate, with the exchange limited to PLN 500 per person, other amounts exchanged concerned legal persons, craft enterprises, local government institutions, and banking enterprises;

3) decree of January 13, 1945 on the withdrawal from circulation in the territory of the Polish State of the currency of the Union of Soviet Socialist Republics [ Dz. U. (Journal of Laws) Nr 2, pos. 5.], on the basis of which on February 15, 1945 the currency of the USSR ceased to be a legal tender in the territory of the Polish state, and exchange took place at the exchange rate 1 ruble $=1$ PLN;

4) decree of February 5, 1945 on the deposit and exchange of German Marks in the territories of the Republic of Poland, liberated from occupation after January 6, 1945 [ Dz. U. (Journal of Laws) Nr 5, pos. 17.], according to which the Mark ceased to be a means of payment on February 28, 1945 , and the exchange ratio was 1 PLN = 2 German brands; in addition, the exchange amount was limited to 500 German Marks per natural person;

5) decree of February 5, 1945 extending the binding force of certain provisions of the decree of January 6, 1945 on the deposit and exchange of banknotes of the Bank of Issue in Poland into the territories of the Republic of Poland, released after January 6, 1945 [ Dz. U. (Journal of Laws) Nr 5, pos. 18.];

6) ordinance of the Minister of the Treasury of May 25, 1945 on the replacement of German Marks on the territory of the former Free City of Gdańsk, which is part of the Gdańsk province [ Dz. U. (Journal of Laws) Nr 21, pos. 127. See more: Landau Z. 1964; Landau Z. 1968].

The implemented currency reform was typically deflationary. There was a reduction in the cash flow by around $60 \%$. The total amount of tickets released by the National Bank of Poland (hereinafter: the NBP) was PLN 4 billion, and the circulation of banknotes of the Bank of Issue in Poland amounted to over PLN 10 billion. As a result, obtained were:

1) an emission margin that allowed the then popular government to make payments for the economic reconstruction of Polish lands and to fi- 
nance the activities of the state administration, because the tax apparatus was not able to provide the necessary budgetary revenues;

2) the increase in commodity prices was hindered by the reduction of the purchasing power of the population;

3) so-called speculators, i.e. people who accumulated large amounts of cash during the occupation, were deprived of cash [Karpiński Z. 1968: 173-174].

The implemented monetary reform was similar to currency reforms in other then-existing countries, such as Belgium, France, Norway, Denmark, the Netherlands, and thus was not a socialist reform related to the construction of a new political, social and economic system [Karpiński Z. 1968: 174-175]. In practice, it did not cause a rise in commodity prices, although initially the exchange was often of a barter type, and the issuance of money grew three times, from PLN 8.7 billion at the end of April 1945 to PLN 26.3 billion at the end of 1945 [Karpiński Z. 1968: 176-177].

However, the currency reform did not specify a case regarding the repayment of old monetary claims, taken mainly in the Polish currency from before September 1939. This involved the problem of valorisation of monetary liabilities. A similar situation took place in the period of the Second Polish-Lithuanian Commonwealth, specifically the so-called the first stabilization of the zloty in 1924. At that time, the ordinance of the President of the Republic of May 14, 1924 on the rescheduling of private-legal liabilities $^{3}$, referred to as lex Zoll, on the basis of which the valorisation of pecuniary obligations prior to the introduction of the zloty was made [Jastrzębski R. 2016]. It is worth noting that the courts after 1945 applied the principle of valorisation of benefits based on the rebus sic stantibus clause, pursuant to art. 269 of the Code of obligations ${ }^{4}$. Therefore, on October 7, 1948, the Ministry of Justice issued a recommendation according to which in cases resulting from prewar private law obligations the courts were to withhold their recognition until the final statutory regulation and in cases settled by court judgments had and in the case of cases resolved by court judgments, all enforcement actions were to be immediately suspended [Jastrzębski R. 2009: 413 - 417].

${ }^{3}$ Dz. U. (Journal of Laws) No. 42, item 441 (consolidated text: Journal of Laws of 1925, No. 30, item 213)

4 Ordinance of the President of the Republic of October 27, 1933 - Code of Obligations, Dz.U. U. No. 82, item 598 
Subsequently, a decree was issued on July 27, 1949 on taking new and determining the amount of unpaid cash obligations [ Dz. U. (Journal of Laws) No. 45, item 332.]. The decree was nominalistic in accordance with art. 5 change in the purchasing power of money, in the time between the occurrence of the liability and its due date or performance, did not constitute grounds for changing the amount of the performance or the manner of performance or termination of the contract. Therefore, the repayment was made in the Polish currency, i.e. NBP tickets, in the nominal amount. It resulted from the fact that PLN 1 of the Bank of Poland (before the outbreaks of the Second World War) $=1$ PLN Bank Emisyjny in Poland = PLN 1 National Bank [Domański L. 1949; Zieliński P. L. 1950]. In some cases, it was possible to additional payments, incl. if the cash liability, based on the private law title, was established before the introduction of NBP tickets, and the creditor at the time of the obligation and application for the subsidy derived income excluding from running a small farmer or from remuneration for work in the amount specified in a separate Council Regulation Ministers.

In the second half of 1946, there was an increase in the circulation of money, which was caused by the implementation of the so-called a threeyear plan (1947-49), which mainly concerned the growth of industrial production. It is worth noting that in 1947/1948 took place, among others the so-called battle for trade, the consequence of which was the increase in the share of the socialized sector in trade, and the paper system was gradually being phased out. This resulted in an increase in the cash flow in 1947-49, which amounted to 26.3 billion in 1945, and in subsequent years: 1946: 60.1 billion; 1947, 91.5 billion; 1948, 130.7 billion, and in 1949, PLN 171.9 billion. In this way, an increase in employee salaries and free market prices was somewhat automatic. Therefore, it was necessary to conduct another monetary reform, and its implementation was planned for three years before its actual implementation. It should be noted that in other countries the so-called the Eastern bloc currency reforms after the end of the war were also carried out in two stages, e.g. in Romania and Bulgaria $(1947,1952)$, in the German Democratic Republic $(1948,1957)$ and Czechoslovakia $(1945$, 1953) [Karpiński Z. 1968: 188-191].

Another currency reform from 1950 was prepared in secret from the public, and its implementation in practice was provided by the army, which in one night transported the chests with the new currency [Karpiński Z. 1968: 192-193]. The implementation of the so-called a six-year plan (1950 - 55), one of which was precisely the currency reform [see more: Landau 
Z. 1974: 158-161; Kucharski M. 1975: 76 et seq.]. The Foreign Exchange Reform Act of 1950 was adopted at a closed session of the Sejm ${ }^{5}$ (the lower chamber of the Polish parliament) and was in force with only minor changes until the 1990s. The reform objectives were set out in the preamble to the Act and concerned:

1) the support of the national economy on high-value, sustainable money;

2) restraining and limiting the activities of exploiters and speculators;

3) creating the basis for an increase in savings of working people and effective struggle for a cost-effective and rational national economy;

4) determining the proper ratio of Polish currency to the currencies of capitalist countries.

It follows that the reform was meant to be 'very class-conscious', and its aim was to liquidate ' $2 / 3$ of the capital accumulated in monetary form' and certain specific sources of capitalist profits, including 'Culack monetary stocks' [Herer W. 1950: 65] ${ }^{6}$. Of course, the law on monetary reform was of a general nature, it was not limited to the text of the act itself, but included executive acts of a lower rank. ${ }^{7}$

A monetary unit in the Polish state, in accordance with art. 1 of the Act, was the zloty equal to 0.222168 grams of pure gold, which meant according to the gold standard that 1 zloty $=1$ ruble, and 4 zlotys $=1$ USD [Karpiński Z. 1968: 193]. This parity was abolished only on 1 July 1982 ${ }^{8}$, and as Zenobia Knakiewicz said:

5 The Act of 28 October 1950 on the change of the monetary system, Dz. U. (Journal of Laws) No. 50, item 459.

${ }^{6}$ Justification for the reform see Resolution of the Council of Ministers of October 28, 1950 regarding the change of the monetary system, Monitor Polski No. A - 116, item 1446.

7 See. for example, the order of the Minister of Finance of 30 October 1950 regarding the acceptance by the General Insurance Company of Mutual Insurance provided for reinsurance abroad, Monitor Polski No. A - 121, item 1483; resolution of the Council of State of November 11, 1950 regarding interpretation and establishing rules for the application of art. 8 of the Act of 28 October 1950 on the Change of the Money System (Journal of Laws No. 50, item 459) and $\S 3$ of the Regulation of the Council of Ministers of October 28, 1950 on determining the conversion ratio of certain obligations (Journal of Laws No. 50 , item 461), Monitor Polski No. A - 123, item 1515; Regulation of the Minister of Justice of January 3,1951 on the mode of disclosure in the land and mortgage registers of the mortgage claims conversion, Dz. U. (Journal of Laws) No. 2, item 13; Regulation of the Council of Ministers of February 3, 1951 regarding the rounding of sums in the provisions on payroll tax, Dz. U. (Journal of Laws) No. 9, item 68.

${ }^{8}$ According to art. 96 par. 2 of the Act of 26 February 1982 Banking Law (Journal of Laws No. 7, item 56). 
(...) until June 30, 1982, the zloty had a parity in gold. From the very beginning, however, there was no economic link between our monetary unit and gold. The parity, and thus the parity course, was determined in an administrative manner, without taking into account the purchasing power of the zloty, regardless of the negative effects that this had on the whole national economy [Knakiewicz Z. 1984: 74-75].

The exchange of circulating NBP banknotes for new ones, in the period from October 30 to November 8, 1950, was set without a 100\% limit in the amount of 100: 1. Up to then banknotes, as a rule, ceased to be a legal tender after the end of October 29, 1950. Whereas recalculating e.g. public and private law liabilities, if the creditor was the so-called a social economy unit, in respect of a business relationship, a contract of employment, savings deposits in banking institutions, occurred in a ratio of 100: 3 , on the basis of the regulation of the Council of Ministers of October 28,1950 on determining the ratio of the conversion of certain liabilities [ Dz. U. (Journal of Laws) No. 50, item 461.]. The exception was the unredeemed liabilities of pre-war insurance companies under personal insurance, i.e. pre-war life insurance policies, which were converted into new zlotys at a ratio of 100: 100, according to the regulation of the Council of Ministers of 27 June 1959 determining the ratio of claims conversion insurance contracts for liquidated insurance companies [Po reformie pieniadza... 1950; Malicki J. 1955; Karpiński Z. 1968: 194-196; Dz. U. (Journal of Laws) No. 39, item 243.]. As a result of the reform, the population was deprived of 2/3 of the cash held, which was 'a specific tax on the financial resources accumulated by individual units' [Kurowski L. 1950: 838], and the state obtained the new so-called emission margin. However, even in 1951, the value of the zloty (its purchasing power) could be observed, and the state covered the deficit more and more by printing money. The circulation of money increased at the end: in 1950, it amounted to PLN 4.6 billion, in 1951 - to PLN 5.6 billion, in 1952 - to PLN 6.2 billion, and in 1951 - 53 the average inflation rate exceeded 20\% [see more: Karpiński Z. 1968: 198-199; Landau Z. 1974: 158-159]. The next reform, however, was out of the question for political and systemic - social reasons. Therefore, in practice, the nature of currency reforms, issued by the authorities at the time, regarding changes in prices and wages, which were to affect the market situation. It was about changes in the prices of basic food products, including wheat flour, sugar, meat, butter, margarine, or rents, including wage increases, pensions, benefits. Importantly, these ordinances appeared in Monitor Polski, and even in the NBP News. The principles of the first such reform were laid down in the resolution of the Council of Ministers of January 3, 
1953 ["News of the National Bank of Poland” 1953: I-VI]. However, this did not stop the increase in the issue of money, the circulation of which finally amounted to: 1953, 8.4 billion, 1954 - 10.1 billion, 1955. PLN 11.6 billion [Karpiński Z. 1968: 199-201].

Then the implementation of the so-called the five-year plan (1956-60), when relative stabilization of commodity prices occurred, and the average annual inflation rate in the later years 1966-70 was only $1 \%$. Therefore, inflation was suppressed by the policy of freezing the prices of basic consumer goods and reducing wage growth. The attempt to free, and in fact realize, prices in December 1970 caused a social protest, which resulted in the change of the then governmental team. Continued financial policy, maintaining a stable level of prices, especially basic foodstuffs, was associated with their credited import [Landau Z., Roszkowski W. 1995: 130132]. The repayment of debts to the rest of the world and the related gradual reduction in the mass of goods purchased in other countries, including shortages in the internal market, were associated with increasing social dissatisfaction in the form of strikes. The consequence of this was the inflationary rise in prices, especially visible in the 1980s, when inflation gained momentum and amounted to: $1986-18 \%, 1987-25 \%, 1988-61 \%$, and in 1989 - 244 \% [Landau Z., Roszkowski W. 1995: 135]. It is worth noting that throughout this period the law on the change of the monetary system from 1950 was in effect and the repayment of monetary claims took form in the nominal amount regardless of the change in the purchasing power of the Polish monetary unit, which caused serious legal problems. [see more: Łętowska E. 1985; Łętowska E. 1986; Oleszko A. 1986; Piasecki K. 1986; Nowicka A. 1989]. Carrying out the so-called political and economic transformation resulted in the adoption of the Act of 7 July 1994 on the denomination of the zloty [Dz. U. (Journal of Laws) No. 84, item 386.]. The regulation introduced into circulation a new monetary unit, which pursuant to art. 2 of the Act replaced the previous one in the relation 1: 10,000, and repealed the Act of 1950 .

\section{CONCLUSIONS}

Monetary reforms in the Polish state after the Second World War were proceeding in a different political and economic situation than in the period of the Second Republic of Poland. The reform of 1945 was typically deflationary and also resembled similar reforms in the areas of occupied 
countries, on which the occupation currency introduced by the German state circled. [Karpiński Z. 1968: 173-177]. However, the reform of 1950 was an important factor in the new political, social and economic changes. It was explicitly stated that: 'our money is at the same time an important instrument of economic struggle with capitalist elements' and 'our monetary reform undoubtedly improved the operation of our money as an instrument of socialist planning' [Herer W. 1950: 55, 66-67]. By contrast, subsequent currency reforms after 1950 consisted of periodic changes in prices and wages, and took the form of legal acts of a nature of orders. In fact, they caused a decrease in the purchasing power of circulation money.

In this way, the role of money in the socialist economy was changed, which was only a means to achieve specific political and social goals by the state. Also related to this was the Polish inflation policy pursued by the then state, aimed mainly at covering the deficit. This was, in fact, the imposition of a tax on the general public. It follows that after the Second World War inflation was suppressed and only in the late 1980s took on the character of a galloping inflation. It is worth noting that inflation of that period was inflation of shortages, or permanent shortages of goods, often of basic necessities. Of course, the end of the hyperinflation period or galloping inflation occurs when the state does not receive significant income from economic policy, and the expansion of legal, economic and social relations is a threat to its economic existence. Therefore, it was necessary to carry out an economic reform, the important point of which is the exchange of inflationary money for a new monetary unit, which took place in the Polish state on January 1, 1995, when the law of 7 July 1994 on the denomination of the zloty entered into force.

\section{BIBLIOGRAPHY}

Belka M. (1994), Inflacja [Inflation], [in:] Elementarne Zagadnienia Ekonomii [Elementary Economy Issues], Milewski Roman (red.), Wydawnictwa Naukowe PWN, Warszawa.

Biliński L. (1924), Wspomnienia i dokumenty [Memories and documents], t. I [part I], (1846 1914), Księgarnia F. Hoesicka, Warszawa.

Dalton H. (1948), Zasady Skarbowości [The rules of the Treasury], Wydawnictwo Kazimierza Rutskiego, Łódź.

Domański L. (1949), Zobowiązania pieniężne w świetle dekretu z 27 lipca 1949 r. [Monetary obligations in the light of the decree of July 27, 1949.], „Przegląd Notarialny”, II/1949.

Fedorowicz Z. (1962), Pieniadz w gospodarce socjalistycznej (Zarys teorii) [Money in the socialist economy (Outline of theory)], Państwowe Wydawnictwa Naukowe, Warszawa. 
Fedorowicz Z. (1975), Podstawy teorii pieniadza w gospodarce socjalistycznej [The basics of money theory in the socialist economy], Państwowe Wydawnictwa Ekonomiczne, Warszawa.

Grabski Wł. (1927), Druga inflacja polska [Second Polish Inflation], „Ruch Prawniczy, Ekonomiczny i Socjologiczny", 2/1927.

Grabski Wł. (1927), Dwa lata pracy u podstaw państwowości naszej (1924 - 1925) [Two years of work at the basis of our statehood (1924 - 1925)], nakładem Księgarni F. Hoesicka, Warszawa.

Gruber H. (1968), Wspomnienia i uwagi 1892 - 1942 [Memories and remarks 1892 - 1942], Gryf Publications, Londyn.

Herer W. (1950), Reforma walutowa [Currency reform], „Nowe Drogi”, 6/1950.

Jastrzębski R. (2009), Wptyw sity nabywczej pieniądza na wykonanie zobowiąań prywatno-prawnych w II Rzeczypospolitej [The impact of purchasing power of money on the performance of private law obligations in the Second Polish Republic], Wolters Kluwer, Warszawa.

Jastrzębski R. (2013), Polityka inflacyjna państwa polskiego w XX wieku a interes prywatny. Zagadnienia prawne, ekonomiczne $i$ spoteczne [The inflation policy of the Polish state in the 20th century and the private interest. Legal, economic and social issues], [in:] Interes publiczny a interes prywatny w prawie [Public interest and private interest in law], Giaro Tomasz (red.), Stowarzyszenie Absolwentów Wydziału Prawa i Administracji Uniwersytetu Warszawskiego, Warszawa.

Jastrzębski R. (2016), Lex Zoll. Zarys prawno - ekonomiczno - historyczny [Lex Zoll. Legal, economic and historical outline], Wolters Kluwer, Warszawa.

Kalecki M. (1936), Parę uwag o teorii Keynesa [A few notes about Keynes' theory], „Ekonomista", 3/1936.

Karpiński Z. (1964), Kryzys dolara i kapitalistycznego systemu walutowego [The crisis of the dollar and the capitalist currency system], Państwowe Wydawnictwo Ekonomiczne, Warszawa.

Karpiński Z. (1968), Ustroje pieniężne w Polsce od roku 1917 [Monetary systems in Poland since 1917], Państwowe Wydawnictwa Naukowe, Warszawa.

Keynes J. M. (1985), Ogólna teoria zatrudnienia, procentu i pieniądza [General theory of employment, interest and money], Państwowe Wydawnictwo Naukowe, Warszawa.

Knakiewicz Z. (1984), Polskie koncepcje monetarne [Polish monetary concepts], „Ruch Prawniczy, Ekonomiczny i Socjologiczny", 4/1984.

Konstytucja Polskiej Rzeczypospolitej Ludowej z dnia 22 lipca 1952 r. (Dz. U. Nr 33, poz. 232) [Constitution of the Polish People's Republic of 22 July 1952]

Kosikowski C. (1990), Pieniadz jako instytucja prawno - finansowa [Money as a legal and financial institution], [in:] System instytucji prawno - finansowych PRL [System of legal and financial institutions of the People's Republic of Poland], tom V [vol.V], Instytucje systemu pieniężno - kredytowego i ubezpieczen [Institutions of the monetary-credit system and insurance], Weralski Marian (red.), Zakład Narodowy im. Ossolińskich, Wrocław - Warszawa - Kraków - Gdańsk - Łódź.

Krzyżanowski W. (1938), Finansowanie wojny wspótczesnej [Financing modern war], M. Kossakowska, Lublin.

Kucharski M. (1975), Obieg pieniężny [Cash flow], [in:] Finanse Polski Ludowej w trzydziestolесiu (1944 - 1973) [Finances of People's Poland in the Thirty Years (1944 - 1973)], Bien Witold (red.), Państwowe Wydawnictwa Ekonomiczne, Warszawa.

Kurowski L. (1950), Charakterystyka reformy walutowej [Characteristics of currency reform], „Państwo i Prawo”, 5 - 6/1950. 
Kurowski S. (1990), Polityka gospodarcza PRL [The economic policy of the Polish People's Republic], Editions Spotkania, Warszawa.

Landau Z. (1963), Plan stabilizacyjny 1927 - 1930, geneza, założenia, wyniki [Stabilization plan 1927 - 1930, genesis, assumptions, results], Książka i Wiedza, Warszawa.

Landau Z. (1964), Polityka walutowa Polski Ludowej w okresie lubelskim [The currency policy of People's Poland in the Lublin period], „Kwartalnik Historyczny”, LXXI/1964.

Landau Z. (1968), Reformy walutowe na ziemiach polskich w 1945 roku [Currency reforms in Poland in 1945], "Kwartalnik Historyczny”, LXXV/1968.

Landau Z. (1974), Reformy walutowe w latach 1944 - 1950 [Currency reforms in 1944-1950], [in:] Gospodarka Polski Ludowej 1944 - 1955 [Economy of People's Poland 1944 - 1955], Kaliński Janusz, Landau Zbigniew (red.), Książka i Wiedza, Warszawa 1974.

Landau Z., Roszkowski W. (1995), Polityka gospodarcza II RP i PRL [Economic policy of the Second Polish Republic and the Polish People's Republic], Wydawnictwa Naukowe PWN, Warszawa.

Langrod R. (1946), Nasza waluta a nowy system monetarny [Our currency and the new monetary system], „Państwo i Prawo” 3/1946.

Łętowska E. (1985), Zjawisko inflacji a prawo cywilne [Inflation and civil law], "Nowe Prawo", $5 / 1985$.

Łętowska E. (1986), Zasada nominalizmu w kodeksie cywilnym (Ocena regulacji i perspektywy) [The principle of nominalism in the Civil Code (Regulatory assessment and perspectives)], „Nowe Prawo”, 1/1986.

Malicki J.(1955), Reforma systemu pieniężnego [The reform of the money system], „,Gospodarka Planowa", 11/1955.

Młynarski F. (1925), Kryzys i reforma walutowa [Crisis and currency reform], Książnica Atlas, Lwów - Warszawa.

Morawski W. (2008), Od marki do złotego. Historia finansów Drugiej Rzeczypospolitej [From the Mark to the Zloty. Financial history of the Second Polish Republic], Wydawnictwo Naukowe PWN, Warszawa.

Nowicka A. (1989), Nominalizm a inflacja: w oczekiwaniu zmian legislacyjnych [Nominalism and inflation: in anticipation of legislative changes], „Państwo i Prawo”, 9/1989.

Oleszko A. (1986), Zasada nominalizmu w prawie cywilnym [The principle of nominalism in civil law], „Palestra”, 12/1986.

Orłowski M. (1937), Pieniadz [Money], [in:] Private Law Encyclopedia founded by Henryk Konic, Zoll Fryderyk, Wasilkowski Jan (red.), t. III, nakł. Instytutu Wydawniczego „Bibljoteka Polska", Warszawa.

Piasecki K. (1986), Ceny oraz waloryzacja świadczeń w praktyce sąowej (z uwzględnieniem zagadnień legislacyjnych) [Prices and valorisation of benefits in court practice (including legislative issues)], „Nowe Prawo”, 1/1986.

Piłejko K. (1971), Ztoto i dolar [Gold and dolar], Państwowe Wydawnictwa Naukowe, Warszawa.

Po reformie pieniądza [After the money reform], (1950) „Śląskie Wiadomości Gospodarcze”, nr $45-46 / 1950$.

Rutkowski J. (1989), Inflacja w Polsce Ludowej [Inflation in People's Poland], Państwowe Wydawnictwa Ekonomiczne, Warszawa.

Rybarski R. (1922), Marka polska i złoty polski [Polish Mark and Polish Zloty], Perzyński, Niklewicz i S-ka, Warszawa.

Rybarski R. (1935), Nauka Skarbowości [Science of Treasury], Warszawa (reprint Wolters Kluwer, Warszawa, 2015). 
Skubiszewski K. (1960), Odpowiedzialność międzynarodowa za pieniądz okupacyjny [International responsibility for occupation money], „,Ruch Prawniczy, Ekonomiczny i Socjologiczny", 2/1960.

Skubiszewski K. (1960), Pieniądz na terytorium okupowanym. Studium prawnomiędzynardowe ze szczególnym uwzględnieniem praktyki niemieckiej [Money in occupied territory. A legal-international study with a special focus on German practice], Instytut Zachodni, Poznań.

Stelmachowski A. (1965), Nominalizm pieniężny a waloryzacja [Cash Nominalism and Valorisation], "Studia Cywilistyczne”, IV/1965.

Szturm de Sztrem T. (1923), Znaczenie inflacji jako podatku [The importance of inflation as a tax], „Ekonomista”, 3/1923.

Taylor E. (1926), Druga Inflacja Polska. Przyczyny - Przebieg - Środki Zaradcze [Second Inflation of Poland. Causes - Course - Remedies], Gebethner i Wolff, Poznań - Warszawa.

Taylor E. (1926), Inflacja Polska [Polish Inflation], nakł. Poznańskiego Towarzystwa Przyjaciół Nauk, Poznań.

Wasilkowski J. (1948), Zagadnienie nominalizmu pieniężnego w orzecznictwie polskim [The issue of monetary nominalism in Polish jurisprudence], „Państwo i Prawo”, 8/1948.

„Wiadomości Narodowego Banku Polskiego", 1/1953.

Winiecki J. (1986), Źródła inflacji w gospodarce rynkowej i w gospodarce planowej [Sources of inflation in a market economy and a planned economy], Państwowe Wydawnictwa Naukowe, Warszawa.

Robert Jastrzębski - doctor habilitated at the Faculty of Law and Administration of the University of Warsaw. Author of over 80 scientific publications, including books: Functions of the promissory note in the Second Polish Republic (2003), Component houses. Storage contract. Component evidence. Commentary to the Act (2004), The impact of purchasing power of money on the performance of private law obligations in the Second Polish Republic (2009), Competence Court. Competence College. Genesis. Activity. Present day (2014), Lex Zoll. Legal, economic and historic outline (2016), co-author: Commodity exchanges. Comment (2006), Legal regulation of commodity exchange activity in Poland (2007); co-editor of the Small Constitutions. Essential acts of the transitional periods 1919 - 1947 - 1992 (2014). 